\title{
Cancer morbidity in Swedish dry-cleaners and laundry workers: historically prospective cohort study
}

\author{
Anders I. Seldén · Gunnar Ahlborg Jr
}

Received: 31 March 2010 / Accepted: 7 September 2010 / Published online: 1 October 2010

(c) The Author(s) 2010. This article is published with open access at Springerlink.com

\begin{abstract}
Purpose Despite decades of experimental and observational studies, the carcinogenic risks to humans associated with occupational exposure to perchloroethylene (PER) remain uncertain. The aims of the present study were to further examine the possible associations.

Methods A national cohort of dry-cleaning and laundry workers $(n=10,389)$ assembled in 1984 was followed up for new cases of cancer by matching with the Swedish cancer register from 1985 to 2006 (inclusive), and the results were compared with expected frequencies derived from national reference data.

Results Follow-up was complete for $90.9 \%$ of the cohort (2,810 men, 6,630 women). The overall standardised cancer incidence ratio (SIR) for all subjects was close to unity (SIR 0.96; 95\% confidence interval (CI) 0.91-1.02) with a slightly more favourable outcome in women (SIR $0.91 ; 95 \%$ CI 0.85-0.98) than in men (SIR 1.10; 95\% CI 0.99-1.23). Significantly elevated rates of lung cancer (SIR 1.45; 95\% CI 1.03-1.98) and non-Hodgkin's lymphoma (SIR 2.05; 95\% CI 1.30-3.07) were seen in men, but for both types of cancer, the point estimates were similar in genuine laundry workers and dry-cleaners exposed to PER, respectively.
\end{abstract}

\footnotetext{
A. I. Seldén ( $\square)$

Department of Occupational and Environmental Medicine, Örebro University Hospital, 70185 Örebro, Sweden e-mail: anders.selden@orebroll.se

G. Ahlborg Jr

Institute of Stress Medicine, Region Västra Götaland, Carl Skottsbergs gata 22B, 41319 Göteborg, Sweden

G. Ahlborg Jr

Department of Public Health and Community Medicine, Sahlgrenska Academy at the University of Gothenburg, PO Box 414, 40530 Göteborg, Sweden
}

There was no significant excess of cancer of the oesophagus, larynx, uterine cervix, liver, kidney or urinary bladder.

Conclusions The absence of individual or collective data on PER exposure from participating dry-cleaning shops and laundries involved and limited information on exposure time hampered the risk assessment related to PER. However, no clear association between PER exposure and subsequent cancer morbidity in the workers was evident from this historically prospective cohort.

Keywords Cancer epidemiology $\cdot$ Cohort study . Dry-cleaning $\cdot$ Non-Hodgkin's lymphoma .

Perchloroethylene

\section{Introduction}

An ad hoc working group at the International Agency for Research on Cancer (IARC) considered dry-cleaning of textiles to entail exposures that are possibly carcinogenic to humans (Group 2B; IARC 1995a). Among these exposures, perchloroethylene (PER; also recognised as tetrachloroethylene) has been of special interest, and the substance has been upgraded from unclassifiable with regard to carcinogenic risk to humans (Group 3; IARC 1982) through possibly carcinogenic to humans (Group 2B; IARC 1987) to probably carcinogenic to humans (Group 2A; IARC 1995b). In their most recent evaluation, the IARC found consistently positive associations in studies of PER-exposed cohorts for cancer of the oesophagus, cervix and non-Hodgkin's lymphoma (IARC 1995b). In a similar analysis, the US National Toxicology Program (NTP) also found PER "reasonably anticipated to be a human carcinogen" (NTP 2005).

Other scientific bodies have, however, adhered to more conservative risk estimates pertaining to PER. The American 
Conference of Governmental Industrial Hygienists (ACGIH) for instance has labelled PER an animal carcinogen of unknown human relevance (Group A3; ACGIH 2003), and an equally cautious position has been adopted by the Deutsche Forschungsgemeinschaft (DFG) (Group 3B; "a cause for concern but lack of data"; DFG 2007). In a recent critical review, Mundt et al. (2003) specifically noted the ubiquitous lack of valid exposure estimates in the epidemiological literature on PER and cancer, and they concluded that there was no epidemiological support for linking PER to cancer of any specific site. A joint Dutch-Swedish literature review found the epidemiology on PER carcinogenicity to humans inconclusive (de Raat 2003). A series of case-control studies in census-based (1970), merged cohorts of laundry and dry-cleaning workers from four Nordic countries did not yield significantly elevated risks for cancer of the oesophagus, liver, pancreas or kidney nor for non-Hodgkin's lymphoma, whereas an excess of cancer of the cervix was not clearly related to dry-cleaning (Lynge et al. 2006). Using in part the same data base, Travier et al. (2002) found significantly raised incidence rates for Hodgkin's disease and leukaemia (but not for non-Hodgkin's lymphoma) in female but not in male launderers, dry-cleaners and pressers employed in the laundry, ironing or dyeing industry in both the 1960 and 1970 Swedish censuses and followed until 1989. The incidence of cervical cancer was not increased in this particular group.

In Sweden, PER has been the quantitatively most important agent for dry-cleaning during the second half of the 20th century (Kemikalieinspektionen 1990; Johansen et al. 2005), and to assess further the potential carcinogenicity of PER, we decided to follow-up a previously assembled, national cohort of dry-cleaning and laundry workers by cross-linking with the national cancer register.

\section{Materials and methods}

As part of a Scandinavian initiative (Olsen et al. 1990), a nationwide study of pregnancy outcome in dry-cleaning workers, was undertaken in the mid-1980s (Ahlborg 1990a). A questionnaire mailed to all "washing establishments" recorded in the Swedish Postal Address Registry $(\mathrm{n}=1,254)$ yielded a response rate of $37.9 \%$. The questionnaire called for information about both the establishment (company) and the workers over a period of 11 years (1973-1983). Production volumes and washing techniques were requested as well as details of any chemicals used. No information on PER exposure at the company or individual level was available, but estimates of the proportion of PER and other detergents employed (as reported by the companies over the period of interest) were used as proxy. Names and ten-digit personal identity numbers (PINs) of the workers
(Ludvigsson et al. 2009), their occupation, dates of hire and termination of employment were also requested. At least one month duration of employment was required for inclusion in the original study. All data were checked for the present study, and unidentifiable subjects or those not fulfilling original or current inclusion criteria were excluded from the analysis. Data from 14 companies were lost in the process, leaving workers from 461 companies for the study.

The size of the companies involved varied from small family businesses to establishments with several hundred employees. Each subject was assigned to one of three exposure categories based on information from the companies: the PER subgroup (genuine dry-cleaners and laundries with a proportion of dry-cleaning with PER only), the Laundry subgroup (laundries only, no PER) or Other (any combination of water, PER, chlorofluorocarbons (typically Freon 113) and sporadic cases of white spirit, naphta or trichloroethylene). Generally, data on production volumes were missing or considered unreliable but the available information indicated that most companies for which PER drycleaning accounted for a high proportion of their total cleaning volume $(>50 \%)$ were small (cleaning $<500$ tonnes of textiles/year), whereas a high proportion of genuine laundries and laundries with a small PER-based dry-cleaning division were large companies ( $>5,000$ tonnes/year). No systematic data on spot removal chemicals used in drycleaning shops or elsewhere were available.

In Sweden, PER has been used almost exclusively for dry-cleaning since the 1950s (Kemikalieinspektionen 1990; Johansen et al. 2005). National regulation and structural changes within the industry (reductions in demand and improvements in efficiency) have led to a dramatic ( $\sim 95 \%)$ reduction in the consumption (sales) of PER from around 5,000 tonnes/year in the early 1970 s to 300 tonnes/year three decades later ( $\mathrm{R}$ Wettström, personal communication 1993; Swedish Chemicals Agency 2009). No exposure measurements of PER or other dry-cleaning agents were available from the companies in the present study, but in an exhaustive search for historical data from Nordic dry-cleaning establishments, it was concluded that PER exposure levels in the 1970s were of the order of $100-200 \mathrm{mg} / \mathrm{m}^{3}$ (15-30 ppm) (Johansen et al. 2005). Additional information from contemporary Swedish studies indicates that exposure to PER in the early 1980s was variable within and between various dry-cleaning establishments with the 8 -h average exposure level rarely exceeding $50 \mathrm{ppm}$ (Andersson et al. 1981; Lindberg and Bergman 1984; Arbetarskyddsstyrelsen 1988). In the 21 st century, this remains the permissible level for occupational PER exposure for several industrialised countries (Institut für Arbeitsschutz der Deutschen Gesetzlichen Unfallversicherung 2010).

Originally, 10,389 subjects were reported by the companies ("washing establishments"), but 677 (6.5\%) were 
Table 1 Distribution of subjects in a Swedish cohort of dry-cleaning and laundry workers

\begin{tabular}{|c|c|c|c|}
\hline Category & Males & Females & Total \\
\hline Original files & & & 10,389 \\
\hline Excluded & & & 949 \\
\hline Exposure ceased before 1973 & 2 & 26 & 28 \\
\hline Exposure commenced after 1983 & 82 & 164 & 246 \\
\hline Duration of employment $<1$ month & 24 & 76 & 100 \\
\hline $\begin{array}{l}\text { Deceased 1973-1984 } \\
\text { (before follow-up) }\end{array}$ & 60 & 119 & 179 \\
\hline $\begin{array}{l}\text { Emigrated 1973-1984 } \\
\text { (before follow-up) }\end{array}$ & 30 & 94 & 124 \\
\hline Identity unclear & - & - & 200 \\
\hline Other & 27 & 45 & 72 \\
\hline Included (by exposure category) & 2,810 & 6,630 & 9,440 \\
\hline Dry-cleaning with PER ${ }^{\mathrm{a}}, \%$ & 1,877 & 4,479 & 6,356 \\
\hline$<10$ & 940 & 2,466 & 3,406 \\
\hline $10-50$ & 412 & 854 & 1,266 \\
\hline$>50$ & 458 & 1,054 & 1,512 \\
\hline Unclassifiable & 67 & 105 & 172 \\
\hline Laundry & 850 & 2,051 & 2,901 \\
\hline $\begin{array}{l}\text { Other dry-cleaning } \\
\text { (fluorocarbons, white spirit) }\end{array}$ & 83 & 100 & 183 \\
\hline
\end{tabular}

Subjects excluded or lost to follow-up and by exposure category

a Proportion of dry-cleaning with PER in relation to overall annual textile cleaning volume at the company level

excluded for either not fulfilling the original inclusion criteria or other reasons pertaining to the present study design and 272 (2.6\%) were lost in the identification process, leaving 9,440 individuals $(2,810$ men and 6,630 women) to follow-up (Table 1). The vital status as of 31 December 2006 of each cohort member was obtained using a PIN-based match to the national population register and the national cause-of-death register. Dates of emigration, if any, were obtained by reference to the national emigration register. Person-years were counted from 1 January 1985 until 85 years old, death, emigration or the end of the observation period, whichever came first. Emigrants returning to Sweden during the observation period were reintroduced into the study from the day of re-entry and followed up as described. For subjects with several separate episodes of employment in the industry, the total duration was obtained by summing each component period. Incident cases of malignant tumours in the cohort, coded to the 7th revision of the International Classification of Diseases (ICD-7), were obtained by matching to the national cancer register for the period 1985-2006.

The outcome was compared with expected numbers of cancer derived from a computation of the person-years under observation with sex, 5 year age group, calendar year and cause-specific national rates to generate standardised incidence ratios (SIRs) for each cancer site of interest.
The corresponding 95\% confidence intervals (CIs) were calculated assuming a Poisson distribution of the observed events. The Statistical Package for Social Sciences (version 9.0, SPSS Inc., Chicago, Illinois) was used for organising the cohort, whereas the cohort analysis was conducted using Stata software (version 10, StataCorp LP, College Station, Texas).

The study was approved by the Uppsala Regional Ethical Review Board (decision no. 2008/007).

\section{Results}

The overall standardised cancer incidence ratio (SIR) for both genders combined was close to unity (SIR 0.96; $95 \%$ confidence interval (CI) $0.91-1.02$ ) with a slightly more favourable outcome in women (SIR 0.91; 95\% CI 0.85 0.98 ) than in men (SIR 1.10; 95\% CI 0.99-1.23; Table 2). The findings for the female sub-cohort, which accounted for $70.3 \%$ of the entire person-time observed, were primarily due to low rates of malignant tumours of the breast, the skin and melanoma.

Lung cancer rates were elevated in the cohort, with an overall SIR of 1.32 (95\% CI 1.07-1.60), primarily due to increased incidence of the disease in men (SIR 1.45; $95 \%$ CI 1.03-1.98). There was also a significant increase in the incidence of non-Hodgkin's lymphoma (SIR 2.05; 95\% CI 1.30-3.07) in male workers, and the point estimate was increased also for Hodgkin's lymphoma in men, but the confidence interval was wide since only four cases were observed (SIR 2.88; 95\% CI 0.79-7.38). Female workers showed no evidence of increased lymphoma risks.

Cancer of the liver and gallbladder was proportionally more common in men than in women with SIRs of 1.93 versus 0.86 (not significant) based on 11 and 15 observed cases, respectively. Cancer of the uterine cervix was observed slightly more often than expected, but this observation also did not reach statistical significance (SIR 1.25; 95\% CI 0.81-1.85). No cases of cancer of the oesophagus were observed in male workers versus 3.71 expected (data not in table), whereas five cases in female workers gave an SIR of 1.33 (95\% CI 0.43-3.10). Four of these cases were squamous cell carcinomas and the fifth was an adenocarcinoma. A single case of laryngeal cancer in a woman (but no male case) was observed (again not in table). For all other individual cancer sites including the kidney and the urinary bladder, overall risk estimates were within the range expected from random variation.

Further analysis indicated that the overall incidence of cancer in men was similar regardless of their category of exposure, i.e. whether they were laundry workers, exposed to PER or classified as exposed to other dry-cleaning agents (Table 3). This also applied for female workers with point 
Table 2 Cancer morbidity 1985-2006 in a cohort of Swedish dry-cleaners and laundry workers by gender and site

\begin{tabular}{|c|c|c|c|c|c|c|c|c|c|c|}
\hline \multirow[t]{2}{*}{ Site } & \multirow[t]{2}{*}{ ICD-7 } & \multicolumn{3}{|c|}{ Males } & \multicolumn{3}{|c|}{ Females } & \multicolumn{3}{|l|}{$\mathrm{All}^{\mathrm{a}}$} \\
\hline & & Obs & SIR & $95 \% \mathrm{CI}$ & Obs & SIR & $95 \% \mathrm{CI}$ & Obs & SIR & $95 \% \mathrm{CI}$ \\
\hline All & $140-209$ & 337 & 1.10 & $0.99-1.23$ & 769 & 0.91 & $0.85-0.98$ & 1,106 & 0.96 & $0.91-1.02$ \\
\hline Oesophagus & 150 & 0 & - & $0.00-0.99$ & 5 & 1.33 & $0.43-3.10$ & 5 & 0.67 & $0.22-1.56$ \\
\hline Stomach & 151 & 16 & 1.72 & $0.99-2.80$ & 18 & 1.10 & $0.65-1.75$ & 34 & 1.33 & $0.92-1.86$ \\
\hline Colon & 153 & 17 & 0.83 & $0.48-1.33$ & 55 & 0.89 & $0.67-1.15$ & 72 & 0.87 & $0.68-1.10$ \\
\hline Rectum, anus & 154 & 11 & 0.77 & $0.39-1.38$ & 27 & 0.85 & $0.56-1.24$ & 38 & 0.83 & $0.59-1.14$ \\
\hline Liver, gallbladder & 155 & 11 & 1.93 & $0.97-3.46$ & 15 & 0.86 & $0.48-1.41$ & 26 & 1.12 & $0.73-1.64$ \\
\hline Pancreas & 157 & 10 & 1.48 & $0.71-2.72$ & 24 & 1.24 & $0.79-1.84$ & 34 & 1.30 & $0.90-1.81$ \\
\hline Lung & 162 & 39 & 1.45 & $1.03-1.98$ & 61 & 1.24 & $0.95-1.59$ & 100 & 1.32 & $1.07-1.60$ \\
\hline Breast & 170 & 0 & - & $0.00-7.68$ & 219 & 0.88 & $0.77-1.01$ & 219 & 0.88 & $0.77-1.01$ \\
\hline Cervix & 171 & - & - & - & 25 & 1.25 & $0.81-1.85$ & 25 & 1.25 & $0.81-1.85$ \\
\hline Uterus & 172 & - & - & - & 46 & 0.92 & $0.67-1.22$ & 46 & 0.92 & $0.67-1.22$ \\
\hline Ovary & 175 & - & - & - & 40 & 1.03 & $0.74-1.41$ & 40 & 1.03 & $0.74-1.41$ \\
\hline Prostate & 177 & 82 & 0.95 & $0.76-1.18$ & - & - & - & 82 & 0.95 & $0.76-1.18$ \\
\hline Kidney & 180 & 10 & 1.06 & $0.51-1.94$ & 19 & 1.03 & $0.62-1.60$ & 29 & 1.04 & $0.69-1.49$ \\
\hline Bladder & 181 & 18 & 0.86 & $0.51-1.36$ & 20 & 0.98 & $0.60-1.52$ & 38 & 0.92 & $0.65-1.26$ \\
\hline Melanoma & 190 & 10 & 0.76 & $0.37-1.40$ & 17 & 0.52 & $0.30-0.83$ & 27 & 0.59 & $0.39-0.86$ \\
\hline Other skin & 191 & 19 & 1.15 & $0.69-1.80$ & 18 & 0.63 & $0.37-0.99$ & 37 & 0.82 & $0.58-1.13$ \\
\hline Brain, medulla & 193 & 9 & 0.97 & $0.44-1.83$ & 27 & 1.00 & $0.66-1.45$ & 36 & 0.99 & $0.69-1.37$ \\
\hline Thyroid & 194 & 1 & 0.72 & $0.02-4.03$ & 6 & 0.71 & $0.26-1.54$ & 7 & 0.71 & $0.29-1.47$ \\
\hline Other endocrine glands & 195 & 5 & 1.35 & $0.44-3.14$ & 20 & 0.95 & $0.58-1.47$ & 25 & 1.01 & $0.65-1.49$ \\
\hline Connective tissue & 197 & 2 & 0.91 & $0.11-3.28$ & 9 & 1.77 & $0.81-3.36$ & 11 & 1.51 & $0.75-2.70$ \\
\hline Other and unspecified & 199 & 12 & 1.31 & $0.67-2.28$ & 29 & 0.92 & $0.61-1.31$ & 41 & 1.00 & $0.72-1.36$ \\
\hline Non-Hodgkin's lymphoma & 200,202 & 23 & 2.05 & $1.30-3.07$ & 26 & 1.07 & $0.70-1.57$ & 49 & 1.38 & $1.02-1.82$ \\
\hline Hodgkin's lymphoma & 201 & 4 & 2.88 & $0.79-7.38$ & 0 & - & $0.00-1.64$ & 4 & 1.10 & $0.30-2.81$ \\
\hline Multiple myeloma & 203 & 3 & 0.71 & $0.15-2.09$ & 8 & 0.82 & $0.36-1.62$ & 11 & 0.79 & $0.39-1.41$ \\
\hline Lymphoid leukaemia & 204 & 5 & 1.29 & $0.42-3.01$ & 6 & 0.86 & $0.32-1.87$ & 11 & 1.01 & $0.51-1.81$ \\
\hline Myeloid leukaemia & 205 & 5 & 1.64 & $0.53-3.83$ & 6 & 0.82 & $0.30-1.77$ & 11 & 1.06 & $0.53-1.89$ \\
\hline
\end{tabular}

${ }^{a}$ Overall no. of person-years 188,094 (men 55,798, women 132,296)

estimates generally below unity. As for specific cancer sites, the excess of lung cancer was evenly distributed among the two major exposure categories for male workers, whereas among female workers, the increase was confined to laundry workers (SIR 1.63; 95\% CI 1.06-2.39). There was no differential distribution of cancer of the cervix in PER-exposed or laundry workers. The incidence of malignant melanoma was low in both male and female workers within the two major exposure categories but, based on three incident cases, significantly higher than expected in men exposed to other dry-cleaning agents. The excess of non-Hodgkin's lymphoma in male workers was of similar magnitude in both major sub-groups (PER-exposed and laundry workers).

While the cohort was defined as those employed in washing establishments between 1973 and 1983 and assembled in 1984, there was a built-in latency between one and 12 years at the start of follow-up in 1985 . Notably, $35 \%$ of the cohort were included already in 1973 and additionally $12 \%$ before 1976. Application of a 15-year latency requirement (from 1973) therefore provided only marginally different results (data not in table).

Using duration of employment as a proxy for duration of exposure, an inverse relationship of overall cancer incidence and duration of exposure was seen in both male PERexposed and male laundry workers, while the incidence of liver and gallbladder cancer in men showed a tendency in the opposite direction (Table 4). For this site as well as several other less common sites, however, the number of incident cases was low and the risk estimates accordingly unstable. The excess of lymphoma cases in men was conspicuous among PER-exposed workers with the shortest exposure time, i.e. those that had more than one month but less than one year of employment during 1973-1983, yielding an SIR of 6.02 (95\% CI 2.21-13.09). Among male workers with the longest duration of PER exposure 


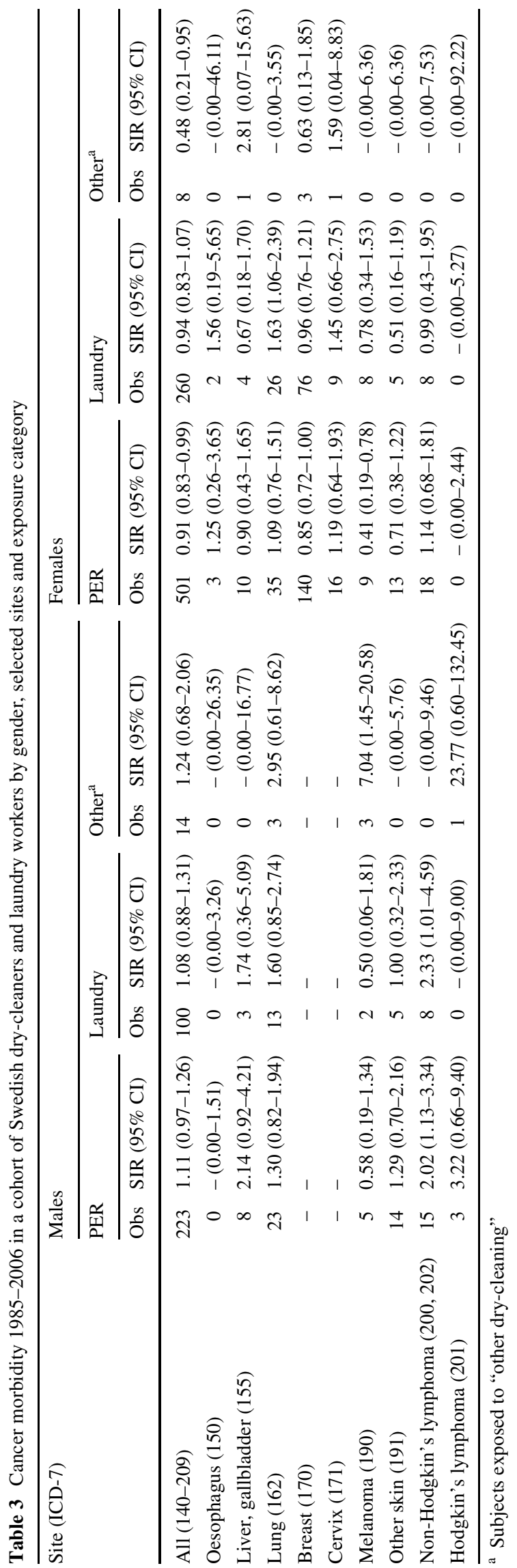

(5-11 years), the incidence of non-Hodgkin's lymphoma was slightly higher than expected (SIR 1.59; 95\% CI 0.64 3.27), while among male laundry workers, the incidence of this disease was highest in those exposed for between one and four years (SIR 4.07; 95\% CI 1.11-10.42).

Irrespective of category of exposure (PER-exposed or laundry employees), neither the overall incidence of cancer nor the incidence of specific cancers was positively correlated with duration of employment in women (Table 4).

As indicated in Table 3, 15 cases of non-Hodgkin's lymphoma were observed in male workers exposed to PER and of these, eight were employees of companies for which $>50 \%$ of the cleaning involved use of PER, resulting in an SIR of 3.57 (95\% CI 1.54-7.04; not in table). When female workers were similarly classified, seven cases of non-Hodgkin's lymphoma were noted (SIR 1.58; 95\% CI 0.64-3.26). Some details of these individual cases, including occupational title, duration of employment, age at diagnosis and pathoanatomical classification (as recorded in the cancer register), are displayed in Table 5, but there was no clear evidence to suggest an association with PER exposure.

\section{Discussion}

In this historically prospective cohort study of cancer incidence in male and female dry-cleaning and laundry workers, an overall cancer incidence close to unity was observed for both genders combined. The placing of employees into discrete exposure categories allowed comparisons to be made between laundry workers who had little contact with chlorinated solvents or other toxic chemicals and dry-cleaning workers with various degrees of exposure to PER. Evidence presented here showed an increase in lung cancer in male workers without a clear association with PER exposure and a similar increase in lung cancer in female workers, which was confined to workers in genuine laundries. In addition, there was a higher than expected incidence of non-Hodgkin's lymphoma in male workers that could not be related to PER. Overall, no specific cancer site or type was clearly associated with PER exposure in either gender.

The present study followed over 9,400 subjects for more than two decades, making it one of the largest cohort studies of dry-cleaners and laundry workers to date apart from census-based investigations (Malker and Weiner 1984; Lynge and Thygesen 1990; Travier et al. 2002). The main strengths of the study were its prospective design with information on crude qualitative PER exposure collected before follow-up; a contrasting subgroup of laundry workers without known PER exposure; a high follow-up rate (97.2\% after exclusions) based on (unique) PINs; the size of the cohort and the long follow-up period plus a valid source for data on the outcome of interest (The Swedish 
Table 4 Cancer morbidity 1985-2006 in Swedish drycleaners and laundry workers by gender site, type and duration of employment

\begin{tabular}{|c|c|c|c|c|c|}
\hline \multirow[t]{2}{*}{ Site (ICD-7) } & \multirow{2}{*}{$\begin{array}{l}\text { Duration of } \\
\text { employment } \\
\text { (years) }\end{array}$} & \multicolumn{2}{|l|}{ PER } & \multicolumn{2}{|c|}{ Laundry } \\
\hline & & Obs & $\operatorname{SIR}(95 \% \mathrm{CI})$ & Obs & SIR $(95 \% \mathrm{CI})$ \\
\hline \multicolumn{6}{|l|}{ Male } \\
\hline \multirow[t]{3}{*}{ All (140-209) } & $<1$ & 36 & $1.62(1.13-2.24)$ & 18 & $1.33(0.79-2.10)$ \\
\hline & $1-4$ & 62 & $1.21(0.92-1.55)$ & 27 & $1.09(0.72-1.59)$ \\
\hline & $5-11$ & 125 & $0.98(0.81-1.16)$ & 55 & $1.01(0.76-1.32)$ \\
\hline \multirow[t]{3}{*}{ Liver, gallbladder (155) } & $<1$ & 0 & $-(0.00-9.71)$ & 0 & $-(0.00-16.04)$ \\
\hline & $1-4$ & 3 & $3.19(0.66-9.31)$ & 0 & $-(0.00-8.20)$ \\
\hline & $5-11$ & 5 & $2.06(0.67-4.80)$ & 3 & $2.87(0.59-8.38)$ \\
\hline \multirow{3}{*}{$\begin{array}{l}\text { Non-Hodgkin's } \\
\text { lymphoma }(200,202)\end{array}$} & $<1$ & 6 & $6.02(2.21-13.09)$ & 1 & $1.68(0.04-9.38)$ \\
\hline & $1-4$ & 2 & $1.00(0.12-3.61)$ & 4 & $4.07(1.11-10.42$ \\
\hline & $5-11$ & 7 & $1.59(0.64-3.27)$ & 3 & $1.62(0.33-4.72)$ \\
\hline \multicolumn{6}{|l|}{ Female } \\
\hline \multirow[t]{3}{*}{ All (140-209) } & $<1$ & 70 & $0.88(0.69-1.11)$ & 35 & $1.06(0.74-1.48)$ \\
\hline & $1-4$ & 154 & $0.90(0.76-1.05)$ & 85 & $0.99(0.79-1.23)$ \\
\hline & $5-11$ & 277 & $0.93(0.82-1.04)$ & 140 & $0.89(0.75-1.05)$ \\
\hline \multirow[t]{3}{*}{ Liver, gallbladder (155) } & $<1$ & 2 & $1.66(0.20-6.01)$ & 1 & $1.84(0.05-10.23$ \\
\hline & $1-4$ & 5 & $1.50(0.49-3.50)$ & 0 & $-(0.00-2.02)$ \\
\hline & $5-11$ & 3 & $0.46(0.09-1.33)$ & 3 & $0.83(0.17-2.41)$ \\
\hline \multirow[t]{3}{*}{ Cervix (171) } & $<1$ & 1 & $0.32(0.01-1.78)$ & 1 & $0.96(0.02-4.81)$ \\
\hline & $1-4$ & 8 & $1.72(0.74-3.40)$ & 2 & $0.90(0.11-3.24)$ \\
\hline & $5-11$ & 7 & $1.24(0.50-2.56)$ & 6 & $2.13(0.78-4.63)$ \\
\hline \multirow{3}{*}{$\begin{array}{l}\text { Non-Hodgkin's } \\
\text { lymphoma }(200,202)\end{array}$} & $<1$ & 4 & $1.95(0.53-5.00)$ & 1 & $1.16(0.03-6.48)$ \\
\hline & $1-4$ & 5 & $1.04(0.34-2.44)$ & 3 & $1.22(0.25-3.57)$ \\
\hline & $5-11$ & 9 & $1.01(0.46-1.92)$ & 4 & $0.84(0.23-2.14)$ \\
\hline
\end{tabular}

Table 5 Some details of non-Hodgkin's lymphoma cases (ICD-7 200, 202) 1985-2006 employed at companies with >50\% PER for dry-cleaning

\begin{tabular}{llllll}
\hline Case no Gender & Occupation & $\begin{array}{l}\text { Duration of } \\
\text { employment } \\
\text { (years) }\end{array}$ & $\begin{array}{l}\text { Age at } \\
\text { diagnosis }\end{array}$ & ICD-7 Morphology & SNOMEDO 10.1 \\
\hline
\end{tabular}

\begin{tabular}{|c|c|c|c|c|c|c|c|}
\hline 1 & Male & Dry-cleaner & $<1$ & 82 & 200.1 & Lymphosarcoma & $\mathrm{NA}^{\mathrm{b}}$ \\
\hline 2 & Male & Driver & $<1$ & 45 & 200.1 & Lymphosarcoma & CB diffuse \\
\hline 3 & Male & Carpet cleaner & $<1$ & 55 & 202.2 & Mycosis fungoides & Mycosis fungoides \\
\hline 4 & Male & Dry-cleaner & $1-4$ & 60 & 200.1 & Lymphosarcoma & T-cell lymphoma \\
\hline 5 & Male & Driver & $5-11$ & 53 & 200.1 & Lymphosarcoma & $\mathrm{CB} / \mathrm{CC}$ follicular lymphoma \\
\hline 6 & Male & Dry-cleaner & $5-11$ & 52 & 200.1 & Lymphosarcoma & Non-Hodgkin's lymphoma \\
\hline 7 & Male & Spot remover & $5-11$ & 64 & 200.1 & Lymphosarcoma & T-cell lymphoma \\
\hline 8 & Male & Foreman & $5-11$ & 74 & 202.4 & Mycosis fungoides & Hairy cell leukaemia \\
\hline 9 & Female & Shop clerk & $<1$ & 81 & 200.1 & Lymphosarcoma & $\mathrm{CB}$ diffuse \\
\hline 10 & Female & Presser & $<1$ & 61 & 200.2 & Lymphoma, unspecified & NA \\
\hline 11 & Female & Seamstress & $1-4$ & 47 & 200.1 & Lymphosarcoma & Non-Hodgkin's lymphoma \\
\hline 12 & Female & Office clerk & $1-4$ & 57 & 200.1 & Lymphosarcoma & NA \\
\hline 13 & Female & Seamstress & $5-11$ & 67 & 200.1 & Lymphosarcoma & NA \\
\hline 14 & Female & Dry-cleaner, presser & $5-11$ & 59 & 200.1 & Lymphosarcoma & $\mathrm{CB} / \mathrm{CC}$ follicular and diffuse lymphoma \\
\hline 15 & Female & Dry-cleaner, presser & $5-11$ & 56 & 200.1 & Lymphosarcoma & Follicular non-Hodgkin's lymphoma \\
\hline
\end{tabular}

\footnotetext{
${ }^{a}$ Systematised nomenclature of medicine, oncology
}

b Not available 
Cancer Register) (Barlow et al. 2009). Moreover, in parallel with the initial study and cohort ascertainment (Ahlborg 1990a), the exposure to PER was qualitatively validated by comparing data provided by the employers (used here) with information from a questionnaire to a subset of women of the cohort (Ahlborg 1990b). Using employer-based information as reference, a slight underreporting of PER exposure by the employees was observed, suggesting that the opposite situation was unlikely on a cohort basis.

Besides the obvious limited power to detect increases in rare cancer sites, this study also had some limitations with respect to assessment of occupational exposure. Firstly, no quantitative data on exposure to the compound of interest, PER, were available at either an individual or company level, so crude surrogate measures had to be used. While this approach is concordant with most other epidemiological studies of cancer in dry-cleaners (Mundt et al. 2003), it has been a consistent problem in evaluating the carcinogenicity of PER in the occupational setting. Secondly, the occupational history of the cohort members was available for a time window of only 11 years, precluding an assessment of possible confounding from occupational exposures outside this period. This could result in non-differential misclassification of subjects into the specific exposure categories used here. Moreover, historical data on PER exposure in Swedish dry-cleaning establishments suggest that exposure levels were generally low already in the 1970s and 1980s (Johansen et al. 2005; Andersson et al. 1981; Lindberg and Bergman 1984; Arbetarskyddsstyrelsen 1988), tending to reduce the power of detecting any carcinogenic risks pertaining to PER.

The so-called healthy worker effect is an example of confounding related to the observation that employed populations tend to have lower mortality or morbidity than the general population used as reference (Monson 1986; Pearce et al. 2007). This observation, however, is rarely a cause for concern in occupational cancer studies, since it is not practically feasible to take risks of future cancer development into account in pre-employment evaluations (Hernberg 1986; Thériault et al. 1994). This argument is considered applicable to the present study. The occurrence of an "unhealthy worker effect", i.e. the increased mortality/morbidity sometimes noted in studies involving unskilled workers with short duration of employment (Juel 1994; Wingren 2006), might be considered as a mirror image of the "healthy worker effect" and more related to lifestyle-associated than strictly occupational risk factors. Some aspects of such lifestyle-related factors are discussed in the following.

The elevated incidence of lung cancer in both male and female workers observed here was not found to be confined to dry-cleaning agent exposure, suggesting alternative risk factors. An association between dry-cleaning and lung cancer has been noted previously in studies of both Scandinavian and North American dry-cleaning and/or laundry workers (IARC 1995a; Ruder et al. 2001; Blair et al. 2003) but confounding from smoking has been difficult to evaluate due to lack of data. In the present study, no data on smoking habits were available from the cohort files, but contemporary investigations at the time of cohort ascertainment provided some useful information about female workers. Unpublished data from case-control studies within the present cohort and from a complementary investigation of laundry and dry-cleaning workers (Ahlborg (1990b) indicated a prevalence of daily smoking before conception of 66-70\% (data based on questionnaires from 349 subjects). These data can be compared directly to the overall rate of daily smoking of $37 \%$ in 4,687 women attending Swedish prenatal care centres in the early 1980s (Ahlborg and Bodin 1991) and to national data from the Swedish Medical Birth Register (Socialstyrelsen 2002), suggesting a considerably higher prevalence of smoking in this particular cohort when compared to other women of childbearing ages. No information on smoking habits was available for male workers, however, and any suggestion of congruence in tobacco use between genders is purely speculative.

Since there are a high proportion of small (family) businesses in the dry-cleaning sector in Scandinavia (Lynge and Thygesen 1990), it is unclear whether the socio-economic disadvantages of US laundry and dry-cleaning workers highlighted by Blair et al. (2003) apply to Scandinavian workers. Further, in the present study, the dry-cleaners tended to be employed in smaller companies than laundry workers, suggesting differential socio-economic conditions within the textile cleaning trade. In addition, little is known about various lifestyle factors like dietary and alcohol habits in this category of (mainly) blue-collar workers. In a nested case-control study, no excessive alcohol habits were found (defined as at least 21 drinks per week) from interviews of dry-cleaners or laundry workers or their next of kin (Lynge et al. 2006), but any contrasts within the study base may have been obscured by recall bias. For the purpose of the present study, some information on alcohol habits was available from the sources indicated in the previous paragraph. Unpublished data from Ahlborg (1990b) showed that $8.7 \%$ of respondents reported alcohol habits subsequently classified as "high" (consuming beer or light wine almost daily and/or stronger alcoholic drinks at least once per week), whereas only $2.7 \%$ of the larger sample of women attending prenatal care centres were classified as "high" consumers of alcohol (Ahlborg and Bodin 1991). Since these data were collected prospectively, before the outcome here was known, they may have some credibility in suggesting an unfavourable lifestyle among the occupational groups of interest, at least in women. On the other hand, skin (squamous cell) cancer and cutaneous 
melanoma, both of which are strongly related to solar (ultraviolet) radiation (IARC 1992), were underrepresented in this study when compared to the general population of Sweden. Again, this observation could be taken to indicate poor socio-economic status (e.g. less availability to sunexposed winter holidays) as much as more favourable lifestyles.

Cancer of the uterine cervix, a site repeatedly appearing in excess in previous studies of PER-exposed workers (IARC 1995b), is now understood as a disease of infectious origin (Schiffman et al. 2007) rather than associated with chemical exposures in working populations. Hence, previous observations of increased rates of cervical cancer in dry-cleaning and laundry workers are best interpreted in terms of socio-economic or lifestyle-related determinants of risk, as discussed earlier. Slightly increased point estimates of cervical cancer were observed in PER-exposed as well as laundry workers included in the present study, corroborating a concept of equal risks.

As for oesophageal cancer, another tumour site showing excess in PER-exposed groups (IARC 1995b), alcohol and smoking are well recognised and synergistic determinants, notably for squamous cell carcinoma (Lagergren et al. 2000; Morita et al. 2010). In this study, the power to evaluate the epidemiology of oesophageal cancer was low, but there was a notable gender difference. Inversely to the general background with a clear male dominance (Chandanos and Lagergren 2009), we observed a non-significant increase in female workers (both in the PER and laundry groups, respectively), whereas in male workers, no cases were observed versus 3.7 expected. These findings would suggest a differential risk panorama between the genders, but due to the low numbers involved, no conclusions can be drawn in this respect.

Non-Hodgkin's lymphoma is a complex conglomerate of disease subtypes (Swerdlow et al. 2008), in contemporary pathology thinking including also Hodgkin's disease (Taylor 2005) and thus creating a considerable challenge for the epidemiologist. The histological characteristics of the non-Hodgkin's lymphomas in workers from companies using a high proportion of PER in this study (Table 5) also showed a wide variation and included both B- and T-cell lymphomas where a common aetiology is difficult to comprehend. Moreover, incident cases in this study were evenly distributed in both male and female PER-exposed and laundry workers, respectively, suggesting equal risk patterns between the groups.

Dry-cleaning with PER might well prove to represent an obsolete technology which may be replaced by a variety of environmentally "green" alternatives (so-called wet cleaning, carbon dioxide-based dry-cleaning and other methods), but the present study has not provided evidence to suggest that PER is hazardous as a human carcinogen.
In conclusion, this historically prospective cohort study of dry-cleaners and laundry workers showed no clear association between occupational exposure to PER and the subsequent incidence of cancer, adding weight to the part of the available epidemiological evidence that suggests absence of such an association.

Acknowledgments Ing-Liss Bryngelsson provided substantial technical assistance. For the initial cohort ascertainment, financial support was obtained from the former Swedish Work Environment Fund.

Conflict of interest The authors declare that they have no conflict of interest.

Open Access This article is distributed under the terms of the Creative Commons Attribution Noncommercial License which permits any noncommercial use, distribution, and reproduction in any medium, provided the original author(s) and source are credited.

\section{References}

Ahlborg G Jr (1990a) Pregnancy outcome among women working in laundries and dry-cleaning shops using tetrachloroethylene. Am J Ind Med 17:567-575

Ahlborg GA Jr (1990b) Validity of exposure data obtained by questionnaire. Two examples from occupational reproductive studies. Scand J Work Environ Health 16:284-288

Ahlborg G Jr, Bodin L (1991) Tobacco smoke exposure and pregnancy outcome among working women. Am J Epidemiol 133:338-347

American Conference of Governmental Industrial Hygienists (2003) Threshold limit values for chemical substances and physical agents and biological exposure indices. ACGIH, Cincinnati $189 \mathrm{pp}$

Andersson I, Bornberger S, Seldén A (1981) Kemtvättprojektet 80/81 (The dry cleaning study 80/81). Report no. 63/81.Örebro, Department of Occupational Medicine, $31 \mathrm{pp}$ (in Swedish)

Arbetarskyddsstyrelsen (1988) Kemtvätterier. Ur: Utredning av konsekvenserna av en halvering av de hygieniska gränsvärdena för organiska lösningsmedel (Dry cleaning. In: Investigation of the consequences of a $50 \%$ reduction of the occupational exposure limits for organic solvents). Rapport 1988:1. Solna, Arbetarskyddsstyrelsen, 104-107 (in Swedish)

Barlow L, Westergren K, Holmberg L, Talbäck M (2009) The completeness of the Swedish Cancer Register-a sample survey for year 1998. Acta Oncol 48:27-33

Blair A, Petralia SA, Stewart PA (2003) Extended mortality follow-up of a cohort of dry cleaners. Ann Epidemiol 13:50-56

Chandanos E, Lagergren J (2009) The mystery of male dominance in oesophageal cancer and the potential protective role of oestrogen. Eur J Cancer 45:3149-3155

de Raat K (2003) Tetrachloroethylene (PER). The Nordic Expert Group for criteria documentation of health risks from chemicals and The Dutch Committee on occupational standards. Arbete och Hälsa 2003:14. Stockholm, National Institute for Working Life, 110 pp. Available 2010-02-25 at https://gupea.ub.gu.se/dspace/ bitstream/2077/4296/1/ah2003_14.pdf

Deutsche Forschungsgemeinschaft (2007) List of MAK and BAT values 2007. WILEY-VCH Verlag GmbH, Weinheim 239 pp

Hernberg S (1986) Validity aspects of epidemiological studies. In: Karvonen M, Mikheev MI (eds) Epidemiology of occupational health. WHO Regional Publications, European Series No. 20. World Health Organization, Copenhagen, pp 269-281 
Institut für Arbeitsschutz der Deutschen Gesetzlichen Unfallversicherung. Tetrachloroethylene (2010) GESTIS International limit values. Available 2010-02-25 at http://bgia-online.hvbg.de/ LIMITVALUE/WebForm_gw.aspx

International Agency for Research on Cancer (1982) IARC monographs on the evaluation of carcinogenic risk of chemicals to humans. Chemicals, industrial processes and industries associated with cancer in humans. IARC Monographs, volumes 1 to 29. Lyon, IARC, Suppl 4, pp 243-245

International Agency for Research on Cancer (1987) IARC monographs on the evaluation of carcinogenic risks to humans. Overall evaluations of carcinogenicity: an updating of IARC Monographs volumes 1 to 42. Lyon, IARC, Suppl 7, pp 355-357

International Agency for Research on Cancer (1992) Solar and ultraviolet radiation. IARC monographs on the evaluation of carcinogenic risks to humans. Lyon, IARC 55:41-290

International Agency for Research on Cancer (1995a) Dry cleaning. IARC monographs on the evaluation of carcinogenic risks to humans. Dry cleaning, some chlorinated solvents and other industrial chemicals. Lyon, IARC 63:33-71

International Agency for Research on Cancer (1995b) Tetrachloroethylene. IARC monographs on the evaluation of carcinogenic risks to humans. Dry cleaning, some chlorinated solvents and other industrial chemicals. Lyon, IARC 63:159-221

Johansen K, Tinnerberg H, Lynge E (2005) Use of history science methods in exposure assessment for occupational health studies. Occup Environ Med 62:434-441

Juel K (1994) High mortality in the Thule cohort: an unhealthy worker effect. Int J Epidemiol 23:1174-1178

Kemikalieinspektionen (1990) Tetrakloretylen. In: Ämnesredovisningar. Bilaga till rapport 10/90. Begränsningsuppdraget-redovisning av ett regeringsuppdrag (The limitation assignment-report from a government assignment). Solna, Kemikalieinspektionen, pp 37-49 (in Swedish)

Lagergren J, Bergström R, Lindgren A, Nyrén O (2000) The role of tobacco, snuff and alcohol use in the aetiology of cancer of the oesophagus and gastric cardia. Int J Cancer 85:340-346

Lindberg E, Bergman K (1984) Perkloretylen, alkohol och leverpåverkan hos arbetare i kemiska tvätterier (Perchloroethylene, alcohol and influence on liver enzymes among dry cleaning workers). Arbete och Hälsa 1984:6. Solna, Arbetarskyddsstyrelsen, 23 pp (in Swedish, English abstract)

Ludvigsson JF, Otterblad-Olausson P, Pettersson BU, Ekbom A (2009) The Swedish personal identity number: possibilities and pitfalls in healthcare and medical research. Eur $\mathrm{J}$ Epidemiol 24:659-667

Lynge E, Thygesen L (1990) Primary liver cancer among women in laundry and dry-cleaning work in Denmark. Scand J Work Environ Health 16:108-112

Lynge E, Andersen A, Rylander L, Tinnerberg H, Lindbohm ML, Pukkala E, Romundstad P, Jensen P, Clausen LB, Johansen K (2006) Cancer in persons working in dry cleaning in the Nordic countries. Environ Health Perspect 114:213-219

Malker H, Weiner J (1984) Cancer-miljöregistret Exempel på utnyttjande av registerepidemiologi inom arbetsmiljöområdet (The CancerEnvironment Registry 1961-73. Examples of the use of register epidemiology in studies of the work environment). Arbete och
Hälsa 1984:9. Solna, Arbetarskyddsverket, 107 pp (in Swedish; English summary)

Monson RR (1986) Observations on the healthy worker effect. J Occup Med 28:425-433

Morita M, Kumashiro R, Kubo N, Nakashima Y, Yoshida R, Yoshina K, Saeki H, Emi Y, Kakeji Y, Sakaguchi Y, Toh Y, Maehara Y (2010) Alcohol drinking, cigarette smoking, and the development of squamous cell carcinoma of the esophagus: epidemiology, clinical findings, and prevention. Int J Clin Oncol 15:126-134

Mundt KA, Birk T, Burch MT (2003) Critical review of the epidemiological literature on occupational exposure to perchloroethylene and cancer. Int Arch Occup Environ Health 76:473-491

National Toxicology Program (2005) Tetrachloroethylene (Perchloroethylene) CAS No. 127-18-4. 11th Report on Carcinogens. US Department of Health and Human Services, 2 pp. Available 201002-25 at http://ntp.niehs.nih.gov/ntp/roc/eleventh/profiles/s169tetr. pdf

Olsen J, Hemminki K, Ahlborg G, Bjerkedal T, Kyyrönen P, Taskinen $\mathrm{H}$, Lindbohm ML, Heinonen OP, Brandt L, Kolstad H, Halvorsen BA, Egenaes J (1990) Low birthweight, congenital malformations, and spontaneous abortions among dry-cleaning workers in Scandinavia. Scand J Work Environ Health 16:163-168

Pearce N, Checkoway H, Kriebel D (2007) Bias in occupational epidemiology studies. Occup Environ Med 64:562-568

Ruder AM, Ward EM, Brown DP (2001) Mortality in dry-cleaning workers: an update. Am J Ind Med 39:121-132

Schiffman M, Castle PE, Jeronimo J, Rodriguez AC, Wacholder S (2007) Human papillomavirus and cervical cancer. Lancet 370:890-907

Socialstyrelsen (2002) Fakta om mammor, förlossningar och nyfödda barn. Medicinska födelseregistret 1973 till 2000 (Facts about mothers, deliveries and newborn babies. The Swedish Medical Birth Register 1973 to 2000). Stockholm, Socialstyrelsen, 48 pp (in Swedish). Available 2010-02-25 at http://www.socialstyrelsen.se/Lists/Artikelkatalog/Attachments/11169/2002-125-12_ 200212513.pdf

Swedish Chemicals Agency (2009) Some chlorinated solvents, turnover in 1993-2007. Sundbyberg, Swedish Chemicals Agency. Available 2010-02-25 at http://www.kemi.se/templates/Page 4021.aspx

Swerdlow SH, Campo E, Harris NL, Jaffe ES, Pileri SA, Stein H, Thiele J, Vardiman JW (2008) WHO classification of tumours of haematopoietic and lymphoid tissues, 4 th ed. IARC WHO classification of tumours, no. 2. WHO Press, Geneva, $439 \mathrm{pp}$

Taylor CR (2005) Hodgkin's disease is a non-Hodgkin lymphoma. Human Pathol 36:1-4

Thériault G, Infante-Rivard C, Armstrong B, Ernst P (1994) Occupational neoplasia. In: Zenz C, Dickerson OB, Horvath EP Jr (eds) Occupational medicine, 3rd edn. Mosby Year Book Inc., St. Louis, pp 813-823

Travier N, Gridley G, De Roos AJ, Plato N, Moradi T, Boffetta P (2002) Cancer incidence of dry cleaning, laundry and ironing workers in Sweden. Scand J Work Environ Health 28:341-348

Wingren G (2006) Mortality in a Swedish rubber tire manufacturing plant: occupational risks or an "unhealthy worker" effect? Am J Ind Med 49:617-623 